\title{
Assessment of lead and cadmium in groundwater sources used for drinking purposes in Jijel (Northeastern Algeria)
}

\author{
Balli N. ${ }^{1,2,3, *}$ and Leghouchi E. ${ }^{2,3}$ \\ ${ }^{1}$ Department of Biological Sciences of the Environment, Faculty of Nature and Life Sciences, University of Abderrahmane Mira of Bejaia, \\ Algeria. \\ 2Laboratory of Environment, Health and Biotechnology, University of Mohamed Seddik Benyahia of Jijel, Algeria. \\ ${ }^{3}$ Department of Environmental and Agricultural Sciences, Faculty of Nature and Life Sciences, University Mohamed Seddik Benyahia of \\ Jijel, Algeria. \\ Received: 07/05/2018, Accepted: 10/07/2018, Available online: 08/08/2018 \\ *to whom all correspondence should be addressed: e-mail: belli_nana@yahoo.fr
}

\begin{abstract}
Groundwater is one of the important sources of drinking water In Jijel (northeastern Algeria). Various analyses have shown critical concentrations of lead and cadmium in several groundwater sources used for drinking. The aim of this study is to evaluate the contamination by lead and cadmium of boreholes and hand-dug wells located in the catchment of the Nile River. Therefore, chemical analysis was performed on drinking water samples from eight boreholes; tow hand dug wells and one spring supplying Jijel city in drinking water. The water samples were examined for the presence of cadmium and lead using the SAA- 6200 Atomic Absorption Spectrophotometer (Shimadzu Corporation). The results of this study show high concentrations of lead (ranged from 72.84 \pm 0.26 to $458.95 \pm 0.55 \mu \mathrm{g} . \mathrm{L}^{-1}$ ) and cadmium (ranged from $12.41 \pm 0.88$ to $33 \pm 0.38 \mu \mathrm{g} . \mathrm{L}^{-1}$ ) in all water samples. These concentrations far exceeded permissible values according to the WHO's drinking water posing a potential health risk for the public. The water quality in the studied area of Nile River basin must be considered very low.
\end{abstract}

Keywords: boreholes, cadmium, drinking water, groundwater; hand-dug wells, lead, Nile River.

\section{Introduction}

Environmental pollution like drinking water and soil pollution by heavy metals is one of the most important issues in the world due to no-biodegradability of the metals and their impact on living organisms in concentration greater than thresholds (Naghipour et al. 2018).

Lead and cadmium are two heavy metals toxic to humans and hazardous to the environment (Prokopowicz et al., 2014; Jones et al., 2017). In humans, severe health implications such as cardiovascular and skeletal diseases, infertility and neurotoxicity are associated with the exposure to heavy metals (WHO, 2011). Moreover, the oncogenic properties of such metals have been demonstrated in several studies (WHO 2011; Colak et al., 2015; Gil and Hernandez, 2015; USEPA, 2015; Fallahzadeh et al., 2017). The oncogenic effects of $C d$ and $\mathrm{Pb}$ are aggravated by chronic exposure to these elements due to their long biological half-life and cumulative properties (Monroy et al., 2014; Cabral et al., 2015).

In the general population, food and water are the most common sources of lead and cadmium exposure (ATSDR 2014; Zang, 2016). Cigarette smoking is another source of exposure to heavy metals such as Cd and Cr (ATSDR, 2014); it can also potentiate the effects of exposure to other sources (Fairbrother et al., 2007b).

The subject of safe drinking water is important topic in the world (Alimoradi et al., 2018) and groundwater is one of the most valuable freshwater drinking water sources being used for the drinking purposes throughout the world (Chabukdhara et al., 2017). However, many chemicals, especially those of through anthropogenic activities origin, can contaminate groundwater. The contamination chain usually follows a cyclic order: industry, atmosphere, soil, water, foods and humans (Usman et al., 2014; Gil and Hernandez, 2015; Geng et al., 2016). Among the various pollutants that affect water resources, pollutants containing heavy metals are particularly important due to their high toxicity, even at low concentrations (Vatandoost et al., 2018). According to the World Health Organization (WHO), heavy metals represent a major group of contaminants in drinking water, and they are considered a serious threat to human health (WHO, 2011). The health risks posed by oral intake of heavy metals are the highest among all other exposure pathways (Zhang et al., 2014a; b).

In Algeria as well as in other developing countries, contamination of drinking water sources by heavy metals has been triggered by rapid urbanization, industrialization and excessive use of agricultural pesticides and chemical fertilizers during the last decades. The geogenic sources also contribute to the wide distribution of heavy metals such as arsenic, lead and cadmium in ground and surface 
water (Bhowmik et al., 2015). Hence, small and rural communities and individuals in these countries regularly consume water with levels of heavy metals above the guideline values (WHO, 2011; Khan et al., 2012). The control of drinking water quality thus continues to be a priority for the government authorities to ensure compliance with health and sanitation requirements (Zhao et al., 2002; WHO, 2011). Yet, there are no regular programmes to monitor heavy metal levels in drinking water sources in Algeria.

Jijel is located in northeast part of Algeria, covering 2398 $\mathrm{Km}^{2}$, and has a 2008 census population of 636.948 inhabitants, with 465822 are 15 years old and more (NSO, 2008), the mean annual temperature is ranging from 11.6 to $26.5^{\circ} \mathrm{C}$ and mean annual precipitation from 9.5 to 189.1 $\mathrm{mm}$. The region is characterized by a number of factors that may increase the risk of the contamination of ground waters with $\mathrm{Pb}$ and $\mathrm{Cd}$ from natural or anthropogenic sources. The goal of this study was to determine the lead and cadmium concentrations in groundwater.

\section{Material and Methods}

\subsection{Sample collection}

The drinking groundwater samples were collected (during dry seasons from 2011 to 2013) from the Nile River bassin in Taher city, approximately twenty kilometres from Jijel area (Fig.1a, 1b). The Jijel area is characterised by sedimentary Mesozoic and Cenozoic land covering metamorphic terrains. Thus, the tertiary coverage is on the Kabyle base or on the Cretaceous flysch series (Djellit, 1987).

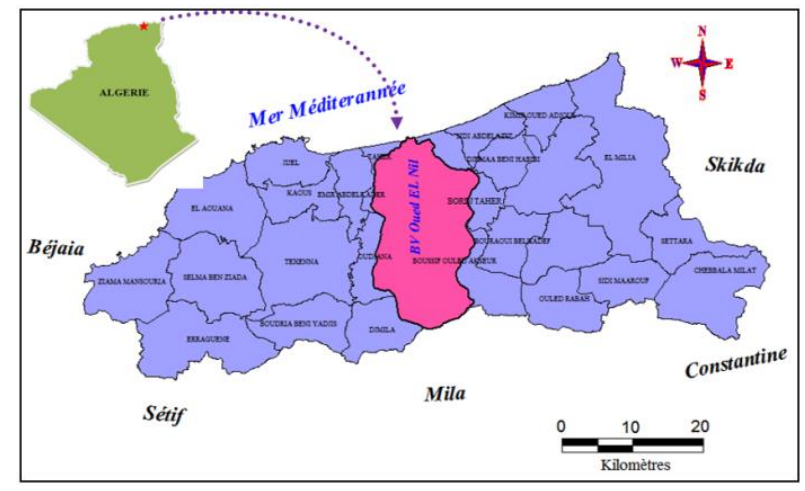

Figure 1a. Jijel area (Zahi et al., 2016).

Ten sampling points were selected for our study. Samples 1 to 7 were collected from different boreholes distributed throughout the Nile River catchment. Samples 8 and 9 were collected from two hand-dug wells, used for drinking water in Redjla, a small village in Taher region. Sample 10 was taken from Bachelot spring near the boreholes, intensively exploited by the local population in Taher city (fig. 2). Three samples were taken from each of these 10 sampling points.

During sampling, the standard guidelines were followed to avoid any possible contamination. Water samples were collected into $250 \mathrm{ml}$ sterile polythene bottles. Once the sample was taken, the bottle was closed immediately, to minimize the formation of air bubbles, and labelled. The bottles were placed in a portable cooler $\left(4^{\circ} \mathrm{C}\right)$ and transported to the laboratory.

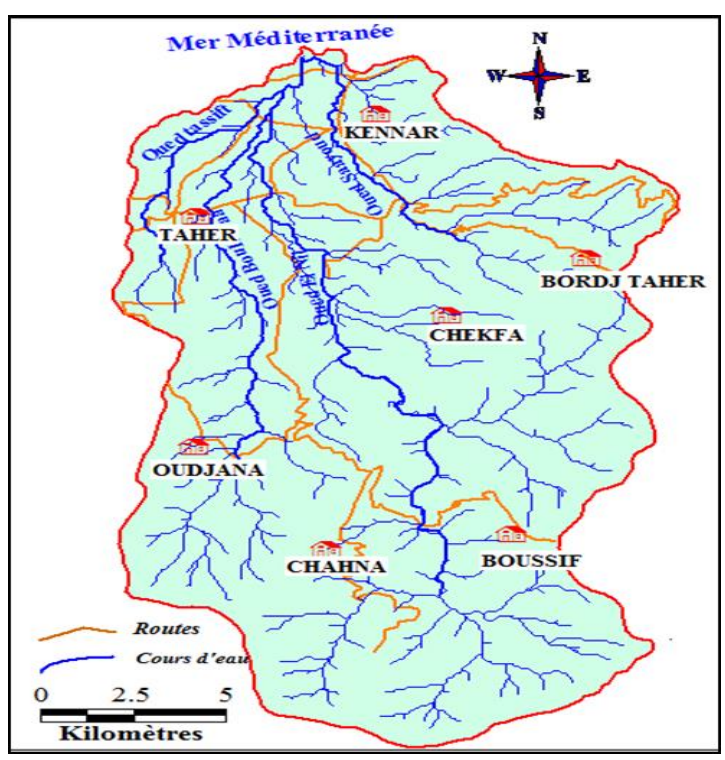

Figure 1b. Nile river catchment (Hammadi and Harendi, 2015).

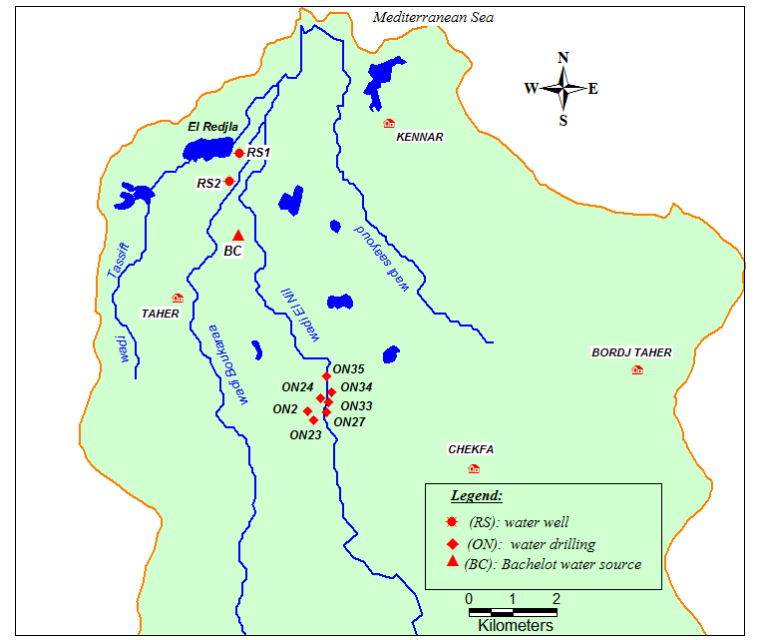

Figure 2. Location of the water-sampling sites.

\subsection{Sample preparation}

Water samples were filtered through $0.45-\mu \mathrm{m}$ filters (Sartorius Stedin, Germany), and the $\mathrm{pH}$ of the filtrate was set to $2 \pm 0.2$ using ultrapure $\mathrm{HNO}_{3}$ (acidification minimises the adsorption of metals into the walls of the container) and stored at approximately $4{ }^{\circ} \mathrm{C}$ in the dark until the analysis.

To ensure the removal of organic impurities from the samples and thus prevent interference in the analysis, the samples were digested according to the ISO 82 88-1986 EC method (Japanese Industrial Standard JIS K-102-1993).

\subsection{Analysis methods}

The water samples were examined for the presence of cadmium and lead using the SAA- 6200 Atomic Absorption Spectrophotometer (Shimadzu Corporation). The detection limits were $10 \mathrm{ug} . \mathrm{L}^{-1}$ for lead and $2 \mathrm{ug} . \mathrm{L}^{-1}$ for cadmium. The 
samples were nebulised in an air/acetylene flame, which atomises the metal elements.

The stock solutions of the reagents were prepared using ultrapure water, and all standard solutions were made daily by diluting the appropriate stock with $0.01 \mathrm{M}$ nitric acid (Tamsi and Cini, 2004). Calibration solutions of the target metal ions were prepared from the standard stocks by serial dilution.

For water samples, $1000 \mathrm{mg} \cdot \mathrm{L}^{-1}$ stock solutions of $\mathrm{Cd}$ and $\mathrm{Pb}$ (AVS Titrinorm, EC) were prepared with $5 \%$ nitric acid and diluted to obtain the calibration curves. The ranges of concentrations chosen corresponded to the concentrations most commonly encountered in drinking water samples.

\subsection{Statistical analysis}

Statistical analysis were performed using Statistical Package for Social Science (SPSS, version 20). The results are expressed as mean \pm SD (SD: standard deviation), with the average concentration of the metal displayed in $\mu \mathrm{g} . \mathrm{L}^{-1}$ after extrapolation from the standard curve. The one-way ANOVA and Scheffe Multiple Comparison method were used to establish if the differences between the concentrations of lead and cadmium at the different sites, during the three years, were significant.

\section{Results}

\subsection{Lead and cadmium concentrations in groudwater samples}

Table1 displays the lead and cadmium concentrations and the descriptive statistics for the groundwater samples from the study area.

The analysis showed hazardous concentrations of lead and cadmium in the groundwater samples collected from different sites, with significantly higher concentrations of lead than cadmium. The highest average level of lead (458.95 $\left.\pm 0.55 \mu \mathrm{g} . \mathrm{L}^{-1}\right)$ was detected in samples collected during 2013 from borehole $\mathrm{ON}_{24}$, and the lowest (72.84 $\left.\pm 0.26 \mu \mathrm{g} . \mathrm{L}^{-1}\right)$ was observed in water samples obtained from Bachelot spring in 2011 (Fig.3a, 3b). Furthermore, all the tests showed the lead levels higher than the drinking water guideline value of $10 \mu \mathrm{g} . \mathrm{L}^{-1}$ recommended by WHO (2011) and by standards Algerian (NA) (JORA, 2011), which might have a detrimental effect on the health of the local population.

Table 1. Lead and cadmium concentrations $\left(\mu \mathrm{g} . \mathrm{L}^{-1}\right)$ in the groundwater samples.

\begin{tabular}{|c|c|c|c|c|c|c|}
\hline \multirow[t]{2}{*}{$\begin{array}{c}\text { Locations of sampling } \\
\text { sites }\end{array}$} & \multicolumn{3}{|c|}{ Lead } & \multicolumn{3}{|c|}{ Cadmium } \\
\hline & 2011 & 2012 & 2013 & 2011 & 2012 & 2013 \\
\hline \multicolumn{7}{|l|}{ Oued Nile's Boreholes } \\
\hline $\mathrm{ON}_{2}($ mean $\pm \mathrm{SD})$ & $348.51 \pm 0.31$ & $354.90 \pm 0.24$ & $431.66 \pm 0.92$ & $28.76 \pm 1.02$ & $29.80 \pm 0.60$ & $28.57 \pm 0.99$ \\
\hline$(95 \% \mathrm{Cl})$ & $347.18-349,85$ & $353.83-355.97$ & $427.69-435.64$ & $24.35-33.16$ & $27.20-32.40$ & $26.10-31.04$ \\
\hline ON23(mean $\pm S D)$ & $258.74 \pm 0.38$ & $267.12 \pm 0.17$ & $272.53 \pm 1.12$ & $14.46 \pm 1.04$ & $19.91 \pm 0.55$ & $20.12 \pm 0.49$ \\
\hline$(95 \% \mathrm{Cl})$ & $257.08-260.40$ & $266.37-267.86$ & $267.69-277.36$ & $9.96-18.95$ & $17.51-22.31$ & $18.88-21.35$ \\
\hline $\mathrm{ON}_{24}($ mean $\pm \mathrm{SD})$ & $452.89 \pm 0.89$ & $458.89 \pm 0.41$ & $458.95 \pm 0.55$ & $32.00 \pm 1.02$ & $32.86 \pm 1.29$ & $32.80 \pm 1.09$ \\
\hline$(95 \% \mathrm{Cl})$ & $451.77-454.00$ & $457.1-460.67$ & $456.54-461.35$ & $27.58-36.41$ & $27.30-38.41$ & $30.07-35.52$ \\
\hline $\mathrm{ON}_{27}($ mean $\pm \mathrm{SD})$ & $335.26 \pm 0.09$ & $335.68 \pm 0.77$ & $335.81 \pm 0.87$ & $24.93 \pm 0.78$ & $25.82 \pm 0.51$ & $26.20 \pm 0.57$ \\
\hline$(95 \% \mathrm{Cl})$ & $334.84-335.68$ & $332.36-339.01$ & $332.03-339.59$ & $21.54-28.33$ & $23.59-28.04$ & $24.78-27.62$ \\
\hline $\mathrm{ON}_{33}($ mean $\pm \mathrm{SD})$ & $378.7 \pm 0.38$ & $396.10 \pm 0.44$ & $404.13 \pm 0.80$ & $30.92 \pm 1.66$ & $32.80 \pm 0.62$ & $33.00 \pm 0.38$ \\
\hline$(95 \% \mathrm{Cl})$ & $377.1-380.46$ & $394.18-398.01$ & $400.68-407.58$ & $23.77-38.07$ & $30.09-35.50$ & $24.78-27.62$ \\
\hline $\mathrm{ON}_{34}($ mean $\pm \mathrm{SD})$ & $318.89 \pm 0.28$ & $321.68 \pm 1.04$ & $321.90 \pm 0.97$ & $13.90 \pm 0.72$ & $16.93 \pm 0.26$ & $17.61 \pm 0.89$ \\
\hline$(95 \% \mathrm{Cl})$ & $317.67-320.1$ & $317.17-326.20$ & $317.84-326.10$ & $10.78-17.02$ & $15.77-18.09$ & $15.38-19.83$ \\
\hline $\mathrm{ON}_{35}($ mean $\pm \mathrm{SD})$ & $275.71 \pm 0.18$ & $283.00 \pm 0.28$ & $294.56 \pm 0.55$ & $12.41 \pm 0.88$ & $12.98 \pm 0.61$ & $13.25 \pm 0.70$ \\
\hline$(95 \% \mathrm{Cl})$ & 274.91-276.51 & $281.79-284.20$ & $292.15-296.96$ & $8.62-16.19$ & $10.34-15.62$ & $11.50-15.00$ \\
\hline \multicolumn{7}{|l|}{ Redjla's wells } \\
\hline $\mathrm{RS}_{1}($ mean $\pm S D)$ & $179.26 \pm 0.32$ & $179.84 \pm 1.5$ & $181.17 \pm 1.03$ & $24.54 \pm 0.32$ & $25.19 \pm 0.16$ & $25.22 \pm 0.45$ \\
\hline$(95 \% \mathrm{Cl})$ & $178,21-181,02$ & $173,35-186,33$ & $179,92-182,42$ & $23,14-25,93$ & $24,48-25,89$ & $24,09-26,36$ \\
\hline RS2(mean \pm SD & $168.34 \pm 0.56$ & $170.04 \pm 0.18$ & $206.02 \pm 0.51$ & $13.69 \pm 0.93$ & $13.87 \pm 0.68$ & $13.94 \pm 0.52$ \\
\hline$(95 \% \mathrm{Cl})$ & $165.89-170.79$ & $169.24-170.84$ & $204.00-208.40$ & $9.65-17.72$ & $10.92-16.82$ & 13.34-14.54 \\
\hline \multicolumn{7}{|l|}{ Bachelotspring } \\
\hline $\mathrm{BC}($ mean $\pm \mathrm{SD})$ & $72.84 \pm 0.26$ & $72.89 \pm 0.63$ & $74.32 \pm 0.32$ & $19.13 \pm 0.35$ & $19.18 \pm 0.58$ & $19.22 \pm 0.37$ \\
\hline$(95 \% \mathrm{Cl})$ & 71.70-73.99 & $70.15-75.64$ & 72.91-75.72 & $17.59-20.66$ & $17.73-20.62$ & $18.28-20.16$ \\
\hline
\end{tabular}

SD: standard deviation; $95 \%{ }^{\mathrm{Cl}}$ : 95\% confidence interval

The Scheffe Multiple Comparison test showed that the mean lead levels significantly differed between most study sites, except for the comparison between borehole $\mathrm{ON}_{35}$ and hand-dug well RS 1 during 2011. For cadmium levels, the ANOVA test showed significant differences between the site groups (boreholes, hand-dug wells and Bachelot spring) during the three years. Moreover, the Scheffe test revealed a significant increase in cadmium and lead levels during this time. These findings confirm the local variations in lead levels and, to a lesser degree, in cadmium levels in the water sources analysed in this study.

An abnormally high concentration of cadmium was found in all the water samples from boreholes and wells, above the permissible limit of $3 \mu \mathrm{g} \cdot \mathrm{L}^{-1}$ (WHO, 2011) and the Algerian limit estimated by $2 \mu \mathrm{g} \cdot \mathrm{L}^{-1}$ (OJAR, 2011). This was particularly pronounced in the borehole $\mathrm{ON}_{33}$ $\left(33 \pm 0.38 \mu \mathrm{g} . \mathrm{L}^{-1}\right)$. The lowest concentration was reported for borehole $\mathrm{ON}_{35}$ : $12.41 \pm 0.88 \mu \mathrm{g} \cdot \mathrm{L}^{-1}$, during 2011 . 


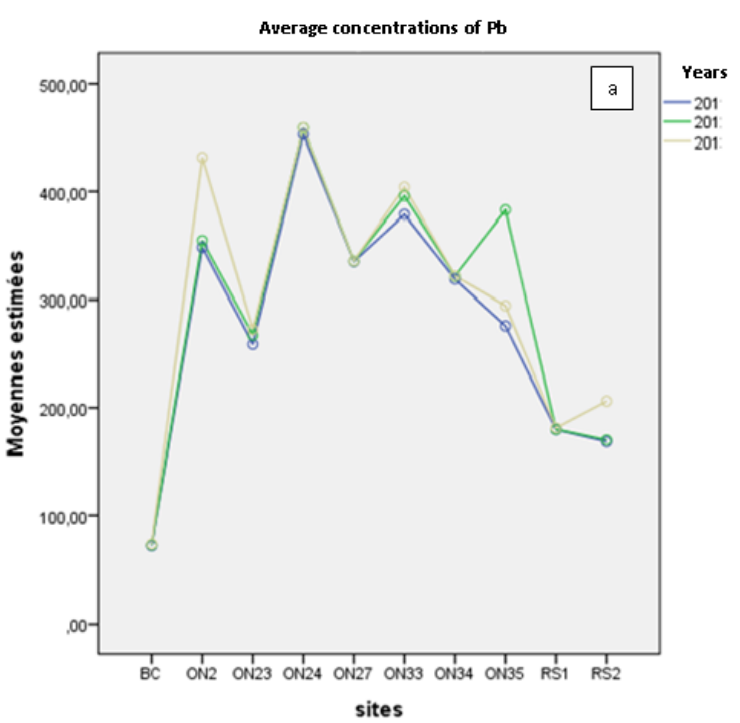

Figure 3. Variations in mean concentrations of lead (a) and cadmium (b) over the three years of the study

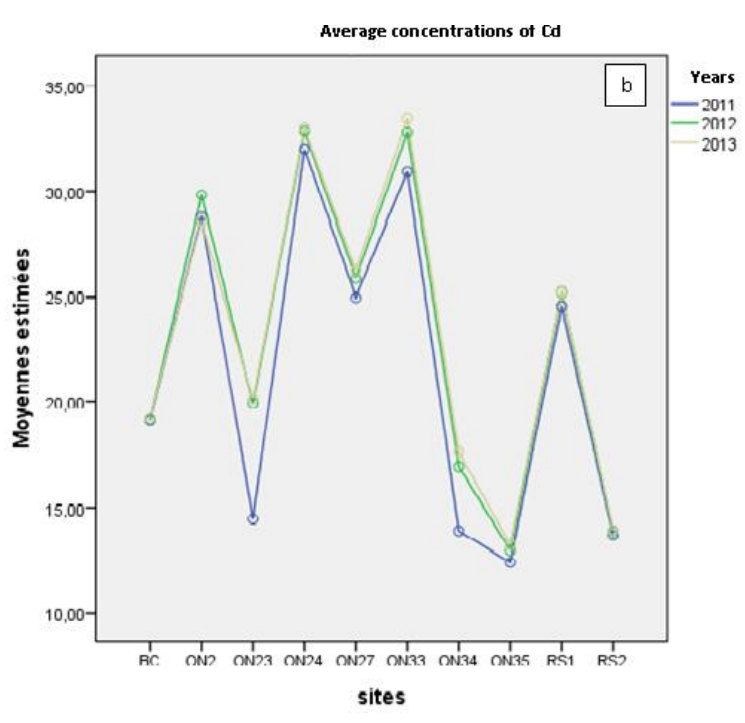

ore area, in the Taher region (Southeast of Jijel). This area contains celsian, magnetite and barite deposits.

A comparison of Taher mineralisation with some similar $\mathrm{Pb}$ $\mathrm{Zn}$ deposits elsewhere in the world suggests a syngenetic hydrothermal origin for these mineral concentrations. The presence of this type of mineralisation in the massif of Petite Kabylie indicates an old metallogenic event, typical of the Northern Algerian socles (Afalfiz et al., 1998).

The natural processes alone may not be a sufficient explanation of the observed metal concentrations. The results of this study clearly demonstrate that the concentration of lead and cadmium increases yearly; this suggests some anthropogenic effects. Heavy metals such as lead and cadmium are mainly introduced into the groundwater by agricultural and industrial activities, landfilling, mining and transportation. The transport and final fate of these metals in the groundwater might follow several distinct paths (Adriano, 2001).

All boreholes and wells analysed here were located in the area used for intensive agriculture (Nile River basin). In some countries, lead added to petrol has also accounted for some of the increase in its concentration in the environment (Petit et al., 2015, Kira et al., 2016). In Algeria, the concentration of lead in the petrol is $0.45 \mathrm{~g} . \mathrm{L}^{-1}$ (Semadi and Deruelle, 1993). One of the other sources of lead might be the waste from old mines of precious metals (gold and silver) and marble. These mines ceased production and were abandoned in 1993. They have been run by Algerian Society of Mines SONAREM in the Nile River basin Ain Tizi in Chahna mountains in the south of Taher. The Bachelot spring and Nile basin boreholes, located downstream from this site, are particularly affected. The domestic sewage and atmospheric deposits are likely to be other anthropogenic sources of this contamination.

The results of this study show that the groundwater from boreholes in the Nile River basin is not safe for human consumption. The water from the boreholes and hand-dug wells was heavily contaminated, with more than 
permissible levels of lead and cadmium. This contamination is about 30 times higher than Algerian standards for lead and about 12 times the Algerian cadmium standards.

Among all heavy metals, lead $(\mathrm{Pb})$ has recently gained increased interest due to its potential to cause various toxicological effects in humans, such as anemia, liver and kidney damage, cardiovascular and haematological damage, central nervous system damage and cancer (Kira et al., 2016; Naghipour et al., 2017). The first manifestation of Cd toxicity is renal tubular dysfunction, a major cause of end-stage renal disease. Long-term exposure has been associated with bone diseases, alteration in lung function, lung cancer, prostate cancer and renal cancer. However, the kidney is the critically affected organ (Verougstraetea et al., 2003; Nair et al., 2013; Arain et al., 2014).

Our analysis exposes serious toxicological threats to the health of the Jijelian population.

\section{Conclusion}

This study was carried out to examine the quality of groundwater from certain boreholes and collective handdug wells, intensively exploited by the local Jijelian population as sources of drinking water. The data showed that the levels of lead and cadmium in water samples examined in this study did not meet the international safety standards. Thus, the water quality in the studied area of Nile River basin must be considered very low.

\section{Acknowledgments}

The authors would like to thank Dr Ewa Gubb (ScienceTextEdit), Dr H. Ouled-Haddar (University of Jijel, Algeria), Dr. P. Luke and Dr A. Lahouel for their assistance in language reviewing. Dr F. Zahi (University of Jijel, Algeria) and Miss S. Habila (University of Jijel, Algeria) are also acknowledged for their technical support.

\section{References}

Adriano D.C. (2001), Trace Elements in Terrestrial Environments: Biogeochemistry, Bioavailability and Risks of Metals, 2nd Edition, Springer, New York, 867p. doi.org/10.1007/978-0387-21510-5

Afalfiz A., Guy B. and Semroud B. (1998), Metallogenic study of polymetallic ore bodies associated with metacarbonates of cristallophyllian Taher region basement; Pelite Kabylie, Algeria, in Recueil de versions abrégées de thèses de géologieminière de l'Algérie. Ph.D. thesis, the Geological Service of Algeria, 9:57-76.

Alimoradi J., Naghipour D., Kamani H., Asgari G., Naimi-Joubani M. and Ashrafi S.D. (2018), Data on corrosive water in the sources and distribution network of drinking water in north of Iran, Data Brief, 17, 105-118. https://doi.org/10.1016/j.dib.2017.12.057.

Alligui F. and Boutaleb A. (2013), Origin and Speciation of Selected Trace Elements in Groundwater: A Case Study of Azzaba District in Northeast of Algeria, Journal of Environment, 2(6), 134-139. Available online at www.scientific-journals.co.uk (accessed 04.08.2017).

Arain M.B., Kazi T.G., Baig A., Afridi H.I., Brehman S.K.D., Panhwar H. and Arain S. (2014), Coexposure of arsenic and cadmium through drinking water and tobacco smoking: Risk assessment on kidney dysfunction, Environmental Science and Pollution Research, 22, 350-357. doi: 10.1007/s11356014-3339-0.

ATSDR (Agency for Toxic Substances and Disease Registry). (2014), Toxicological Profiles.U.S, Department of Health and Human Services, Atlanta, GA. (accessed 22.12.14). http://www.atsdr.cdc.gov/toxprofiles

Belli N., Lahouel M., Chebab S., Tekouk M. and Leghouchi E. (2010), Oxidative stress induced by co-exposition to lead and cadmium, two contaminants of the ground water of Nile wadi (Jijel-Algeria), Water Science, 23(3), 289-230. doi: 10.7202/044690ar

Benhamza M. (1996), Hydrogeological Study of Fendek Mercurial Area (Azzaba)-Effect of Mining on Environment. Ph.D. thesis, University of Annaba, Algeria.

Bhowmik A.K., Alamdar A., Katsoyiannis I., Shen H., Ali N., Ali S.M., Bokhari H., Shäfer R.B. and Eqani S. (2015), Mapping human health risks fromexposure to trace metal contamination of drinking water sources in Pakistan, Science of the Total Environment, 306-316. doi.org/10.1016/j.scitotenv.2015.08.069.

Borah K.K., Bhuyan B.A. and Sarma H.P. (2010), Lead, arsenic, fluoride, and iron contamination of drinking water in the tea garden belt of Darrang district, Assam, India, Environmental Monitoring and Assessment, 169, 347-352. doi: 10.1007/s10661-009-1176-2.

Bradl H. (2005), Heavy Metals in the Environment: Origin, Interaction and Remediation, Heike Bradl (ed), Volume 6, London, 282p.

Cabral M., Toure A., Garçon G., Diop C., Bouhsina S., Dewaele D., Cazier F., Courcot D., Tall-Dia A., Shirali P., Diouf A., Fall M. and Verdin A. (2015), Effects of environmental cadmium and lead exposure on adults neighboring a discharge: Evidences of adverse health effects, Environmental Pollution, 206, 247255. doi.org/10.1016/j.envpol.2015.06.032.

Chabukdhara M., Gupta S.K., Kotecha Y. and Nema A.K. (2017), Groundwater quality in Ghaziabad district, Uttar Pradesh, India: Multivariate and health risk assessment, Chemosphere, doi:10.1016/j.chemosphere.2017.03.086.

Colak E.H., Yomralioglu T., Nisanci R. and Duran C. (2015), Geostatistical analysis of the relationship between heavy metals in drinking water and cancer incidence in residential areas in the Black Sea Region of Turkey, J Environ Health, 77(6), 86-93.

Djellit H. (1987), Tectono-metamorphic evolution of the Kabyle basement and polarization of the layers of flyschs in western Kabylie (Algeria). Ph.D. thesis, University of Paris Sud, French.

Fairbrother A., Wenstel R., Enstel R. and Sappington, K. (2007b), Framework for metals risk assessment, Ecotoxicology and Environmental Safety, 68,145-227. doi:10.1016/j.ecoenv.2007.03.015.

Fallahzadeh R.A., Ghaneian M.T., Miri M. and Dashti M.M. (2017), Spatial analysis and health risk assessment of heavy metals concentration in drinking water resources, Environmental Science and Pollution Research, 24(32), 24790-24802. doi.org/10.1007/s11356-017-0102-3.

Frisbie S.H., Mitchell E.J., Mastera L.J., Maynard D.M., Yusuf A.Z., Siddiq M.Y., Ortega R., Dunn R.K., Westerman D.S., Bacquart T. and Sarkar B. (2009), Public health strategies for Western Bangladesh that address arsenic, manganese, uranium, and other toxic elements in drinking water, Environmental Health Perspectives, 117, 410-416. 
Geng M., Qi H., Liu X., Gao B., Yang Z., Lu W. and Sun, R. (2016), Occurrence and health risk assessment of selected metals in drinking water from two typical remote areas in China, Environmental Science and Pollution Research, 23, 84628469. doi: 10.1007/s11356-015-6021-2.

Gil F. and Hernandez A.F. (2015), Toxicological importance of human biomonitoring of metallic and metalloid elements in different biological samples, Food and Chemical Toxicology, 80, 287-297. doi.org/10.1016/j.fct.2015.03.025.

Hammadi D. and Harendi H. (2015), Integrated management of water resources in the El Nil wadi watershed (Jijel, Algerian $\mathrm{NE})$, Master. Memory. Water and environment, University of Jijel, Algeria.

Jones D.R., Jarrett J.M., Tevis D.S., Franklina M., Mullinix N.J., Wallon K.L., Quarles D.R., Caldwel K.L. and Jones, R.L. (2017), Analysis of whole human blood for $\mathrm{Pb}, \mathrm{Cd}, \mathrm{Hg}$, Se, and $\mathrm{Mn}$ by ICP-DRC-MS for biomonitoring and acute exposures, Talanta, 162, 114-122. doi.org/10.1016/j.talanta.2016.09.060.

Khan S., Shahnaz M., Jehan N., Rehman S., Shah M.T. and Din I. (2012), Drinking water quality and human health risk in Charsadda district, Pakistan, Cleaner Production, 60(3), 93101. doi:10.1016/j.jclepro.2012.02.016.

Kira C.S., Sakuma A.M., De Capitani E.M., Umbelino de Freitas C., Cardoso M.R.A. and Gouveia N. (2016), Associated factors for higher lead and cadmium blood levels, and reference values derived from general population of São Paulo, Brazil, Science of the Total Environment, 543, 628-635. doi.org/10.1016/j.scitotenv.2015.11.067.

Krishna A.K. and Mohan K.R. (2014), Risk assessment of heavy metals and their source distribution in waters of a contaminated industrial site, Environmental Science and Pollution Research, 21, 3653-3669. doi: 10.1007/s11356-0132359-5.

Monroy M., Maceda-Veiga A. and Sostoa A. (2014), Metal concentration in water, sediment and four fish species from Lake Titicaca reveals a large-scale environmental concern, Science of the Total Environment, 487, 233-244. doi:10.1016/j.scitotenv.2014.03.134.

Naghipour D., Ashrafi S.D. and Taghavi K. (2018), Data of heavy metals in soil and groundwater at Kiwi gardens of Amlash in Guilan Province, Iran, Data Brief, 18, 1556-1561. https://doi.org/10.1016/j.dib.2018.04.046

Naghipour D., Jaafari J., Ashrafi S.D. and Mahvi A.H. (2017), Remediation of Heavy Metals Contaminated Silty Clay Loam Soil by Column Extraction with Ethylenediaminetetraacetic Acid and Nitrilo Triacetic Acid, Journal of Environmental Engineering, 143(8), 0401-7026. https://doi.org/10.1061/(ASCE)EE.1943-7870.0001219.

Nair A.R., Degheselle O., Smeets K., Van Kerkhove E. and Cuypers A. (2013), Cadmium- Induced Pathologies: Where Is the Oxidative Balance Lost (or Not)?, International Journal of Molecular Sciences, 14, 6116-43. doi:10.3390/ijms14036116.

Nordberg M., Winblad B., Fratiglioni L. and Basun H. (2000), Lead concentrations in elderly urban people related to blood pressure and mental performance: results from a populationbased study, American Journal of Industrial Medicine, 38, 290294.

OJAR (Official Journal of Algerian Republic)., (2011), Parameters of Quality of the Water of Human Consumption, OJAR No. 18 of March 23, 2011.
ONS (Office National des Statistiques). (2008), Répartition de la population résidente des ménages ordinaires et collectifs âgée de 15 ans et plus selon la situation matrimoniale, Algérie, http://www.ons.dz/Population-RGPH2008-.html (Accessed 17.07.17).

Perkins E.H., Nesbitt H.W., Gunter W.D., St-Arnaud L.C. and Mycroft J.R. (1995) Critical Review of Geochemical Processes and Geochemical Models Adaptable for Prediction of Acidic Drainage from Waste Rock, MEND Rep. No. 1.42.1, MEND, Ottawa, 120.

Petit D., Véron A., Flament P., Deboudt K. and Poirier A. (2015), Review of pollutant lead decline in urban air and human blood: A case study from northwestern Europe, C.R. Geoscience, doi.org/10.1016/j.crte.2015.02.004.

Prokopowicz A., Pawlas N., Ochota P., Szula M., Sobczak A. and Pawlas K. (2014), Blood levels of lead, cadmium and mercury in healthy women in their 50 s an urban area of Poland, Polish Journal of Environmental Studies, 23(1), 167-175.

Rasool A., Xiao T., Farooqi A., Shafeeque M., Masood S., Ali S., Fahad S. and Nasim W. (2016), Arsenic and heavy metal contaminations in the tube well water of Punjab, Pakistan and risk assessment: A case study, Ecological Engineering, 95, 90100. doi.org/10.1016/j.ecoleng.2016.06.034.

Semadi A. and Deruelle S. (1993), Lead pollution monitoring by transplanted lichens in Annaba area (Algeria), Atmospheric Pollution Research, 86-102.

Tamsi G. and Cini R. (2004), Heavy metals in drinking waters from Mount Amiata (Tuscany, Italy): Possible risks from arsenic for public health in the Province of Siena, Science of the Total Environment, 327, 41-51. doi:10.1016/j.scitotenv.2003.10.011

USEPA (U.S. Environmental Protection Agency). (2015), Regulated drinking water contaminants. Online database. Available at: http://www.epa.gov/dwstandardsregulations\#Disinfectants (Accessed on Dec 02, 2015).

Usman O.A., Shuaibu Yinusa I., Funtua A.M. and Akaangee P.A. (2014), Impact of lead and cadmium in drinking water, International Journal of Technical Research and Applications, 2(6), 31-35.

Vatandoost M., Naghipour D., Omidi S. and Ashrafi, S.D. (2018), Survey and mapping of heavy metals in groundwater resources around the region of the Anzali International Wetland; a dataset, Data Brief, 18, 463-469. https://doi.org/10.1016/j.dib.2018.03.058.

Verougstraetea V., Lisona D. and Hotzb P. (2003), Cadmium, lung and prostate cancer: a systematic review of recent epidemiological data, Toxicology and Environmental Health, 6, 227-55. doi: 10.1080/10937400306465.

WHO (World Health Organization) (2011). Guidelines for drinkingwater quality, fourth edition.http://whqlibdoc.who.int/publications/2011/978924 1548151_eng.pdf (verified November 15, 2011).

Zahi F., Drouiche A., Mahdid S. and Debieche T.H. (2016), Water resources assessment in the Wadi Nil catchment (region of Jijel, Algerian East), International Conference on Applied Geology \& Environment "iCAGE2016" Mahdia -Tunisia.

Zang Y. (2016), Cadmium toxicology. In: Caballero B., Finglas P.M. and Toldrá F., (ed) Encyclopedia of Food and Health, vol1: AChe, Elsevier, pp 550-550.

Zhang N.N., Zang S.Y. and Sun Q. (2014a), Health risk assessment of heavy metals in the water environment of Zhalong 
Wetland, China, Ecotoxicology, 23, 518-526. doi: 10.1007/s10646-014-1183-0.

Zhang Y.L., Ma R. and Li Z.H. (2014b), Human health risk assessment of groundwater in Hetao Plain (Inner Mongolia Autonomous Region, China), Environmental Monitoring and Assessment, 186, 4669-4684. doi:10.1007/s10661-014-3729-2.

Zhao X., Holl W.H. and Yun G. (2002), Elimination of cadmium traces contaminations from drinking water, Water Research, 36, 851-858. 